\title{
The Study of Antimicrobial Activity of Citrullus colocynthis Seeds
}
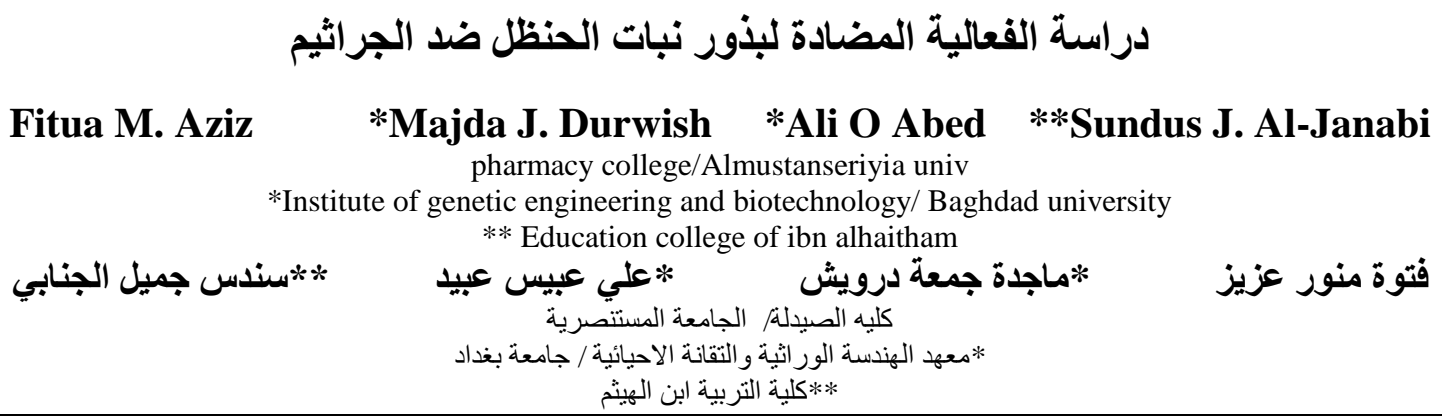

\section{Abstract}

Grude methanolic and hexane extracts of seeds of citrullus colocynthis were examined for antimicrobial effects of different concentrations ranging from (3.150) $\mathrm{mg} / \mathrm{ml}$ against Staphylococcus aureus, Streptococcus pyogenes, Listeria monocytogenes, Bacillus subtilis, Proteus vulgaris, Escherichia coli, Klebsiella pneumoniae, Psendomonas aeruginosa, Salmonella typhi, Entero coccus spp. and Candida albicans. The agar well diffusion methode was used in this study.The extract was found to be active against S.aureus, B.subtilis, $P$. vulgaris, $K$. pneumoniae, and PS. aeruginosa at concentrations of (50, 25, 12.5, 6.25) $\mathrm{mg} / \mathrm{ml}$.while $S$. pyogenes and L.monocytogenes were sensitie at $(50,25,12.5)$ $\mathrm{mg} / \mathrm{ml}$. E. coli shown sensitivity at $(50,25) \mathrm{mg} / \mathrm{ml}$. Enterococcus spp. and Salmonella typhi showed no response. Candida albicans was sensitive to all different concentrations. Hexane extract was less effective against the tested microorganisms than methanolic extract. The results support the notion that Citrullus colocynthis seeds extract may have a role in pharmacentical uses, like antimicrobial drugs.

المستخلص

تم دراسة تأثير المستخلص الكحولي والهكساني لبذور الحنظل بتراكيز تراوحت بين 3.1-50 mg/ml لكلا Staphylococcus aureus, Streptococcus pyogenes, : المستخلصين على نمو الاحياء المجهرية Listeria monocytogenes, Bacillus subtilis, Proteus vulgaris, Escherichia coli, Klebsiella pneumoniae, Pseudomonas aeruginosa, Enterococcus sp, Salmonella باستخدام طريقة الانتشار بال حفر. اشارت النتائج الى ان المستخلص typhi and Candida albicans

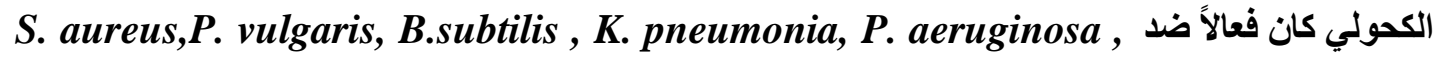
عند التراكيز ( 506.25 , 12.5, mg/ml أما S. pyogenes, L. monocytogenes لبكتريا فقد أبدت

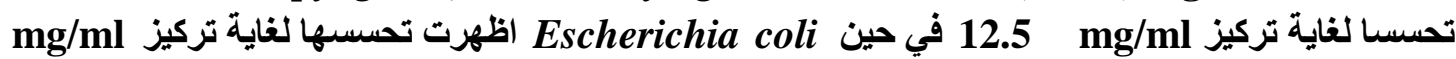

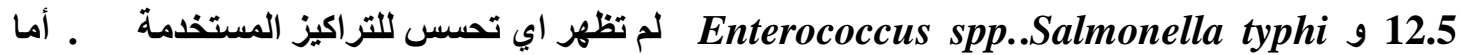

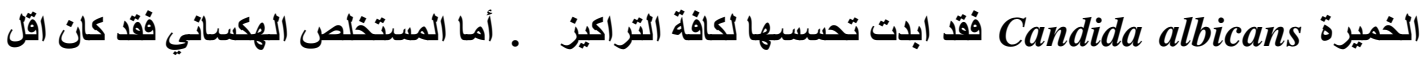

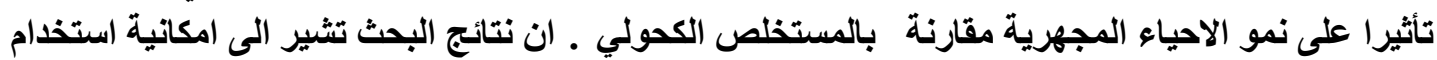
مستخلص بذور الحنظل في المجالات الصيدلانية.

\section{Introduction}

During the last two decades, the development of drug resistance as well as the appearance of undesirable side effects of certain antibiotics [1,2] has lead to the search of new antimicrobial agents mainly among plant extracts with the goal to 
discover new chemical structures which overcome the above disadvantages $[3,4]$. Plants have potent biochemicals and have components of phytomedicine, this natural constituents can be derived from any part of the plant like bark, leaves, flowers, roots, fruits and seeds. Man has exploiting these natural plant products for use in medicine, cosmetics, dyes and food [5].

$\mathrm{Cu}$ cur bitaceae have been used for pharmacological uses in certain areas of the world [6]. Citrullus colocynthis (colocynth, Bitter apple), a member of cucurbitaceae, is an important medicinal plant, the bitter taste and the powerful medicinal virtues of the pulp are due to the presence of amorphous glycoside colocynthin [5]. It has been used for years as a folk and food [7] it used for a menorrhea, bilious disorders, cancer, fever, Jundice, leukemia, rheumatisms, snake bite, tumors and urogenital disorders [3].

The seeds are rich in oil and protein, saponin, an alkaloid, polysaccharide or glycoside and tannin [8]. The present study deals with extraction of Citrullus colocynthis seeds and the antimicrobial activity study against Gram positive, Gram negative bacteria and Candida albicans.

\section{Material and methods}

Citrullus colocynthis seeds: The seeds were collected from herbal drugs shops.

Test microorganisms: All microbial strains used in the study were clinical strains,from health centers laboratories they were Staphylococcus aureus, Streptococcus pyogenes, Listeria monocytogenes, Bacillus subtilis, Proteus vulgaris, Escherichia coli, Klebsiella pneumoniae, Pseudomonas aeruginosa, Salmonella typhi, Enterococcus spp. and Candida albicans.

Preparation of extract: for extraction, methanol and hexane were used as a solvents, thirty grams of the seeds powder were extracted with $300 \mathrm{ml}$ of solvent by using soxhlet apparatus for $10 \mathrm{hrs}$. at a temperate not exceeding the boiling point of the solvent[9]. The extract was filtered by using Whatman No.1 filter paper and the solvent was evaporated using rotary evaporation apparatus. The extract was left at $4^{\circ} \mathrm{C}$ until assessments of their antibacterial activities.

\section{Antimicrobial activities}

For the antimicrobial tests, Hexane extract was diluted in dimethyl sulfoxide (DMSO), while methanol extract was dissolved in distilled water in order to obtain the final concentrations: $(50,25,12.5,6.25,3.1) \mathrm{mg} / \mathrm{ml}$. The agar well diffusion method was used to determine antimicrobial activity of extract [10]. The culture medium was inoculated with one of tested microorganism suspended in nutrient broth. Six millimeters diameter wells were punched into the agar and filled with $0.1 \mathrm{ml}$ of extract. The antimicrobial activity was determined by measuring diameter of inhibition zones in millimeter. Experiment was repeated three times and the mean of diameter of inhibition zones was calculated. Solvents were used as negative control.

\section{Results and discussion}

The present study was conducted to study the in vitro antimicrobial activity of methanol and hexane extracts of Citrullus colocynthis seeds on pathogenic bacteria and Candida albicans. The results showed antibacterial and antifungal activity as shown in Table $(1,2)$. The different concentrations of methanolic extracts of Citrullus colocynthis seeds Table (1) produced inhibition zones against tested bacteria: Bacillus 
subtilis followed by Staphylococcus aureus showed the highest sensitivity to the extract, it produced inhibition zones at concentrations ranging from (50-6.25) mg/ml. Streptococcus pyogenes and Listeria monocytogenes were sensitive at concentrations ranging from (50-12.5) $\mathrm{mg} / \mathrm{ml}$. Proteus vulgaris was the more sensitive bacteria, followed by Klebsiella pneumoniae and Pseudomonas aeruginosa, they produced inhibition zones at concentration of (50-6.25) $\mathrm{mg} / \mathrm{ml}$. Escharichia coli was less sensitive, produce inhibition zones at concentrations of $(50-25) \mathrm{mg} / \mathrm{ml}$. There was no inhibition zone for Salmonella typhi and Enterococcus spp. for all concentrations were used. Candida albicans was sensitive to all different concentrations. Hexane extract of Citrullus colocynthis seeds was less active than methanolic extract.

The antimicrobial activity of hexane extract was shown in Table (2). Staphylococcus aureus showed the highest sensitivity to the extract, it produced inhibition zones at concentrations ranging from $(50-12.5) \mathrm{mg} / \mathrm{ml}$. Streptococcus pyogenes, Listeria monocytogenes and Bacillus subtilis were sensitive at concentrations of (5025) $\mathrm{mg} / \mathrm{ml}$, while E.coli and K.pneumoniae were sensitive to $50 \mathrm{mg} / \mathrm{ml}$.

Table (1): Antimicrobial activity of methanol extract of Citrullus colocynthis seeds

\begin{tabular}{cccccc}
\hline & \multicolumn{5}{c}{$\begin{array}{c}\text { inhibition zone diameter }(\mathbf{m m}) \\
\text { concentrations }(\mathbf{m g} / \mathbf{m l})\end{array}$} \\
ested micro organisms & 50 & 25 & 12.5 & 6.25 & 3.1 \\
Staphylococcus aureus & 20 & 14 & 12 & 11 & - \\
Streptococcus pyogenes & 13 & 12 & 10 & - & - \\
Listeria monocytogenes & 11 & 10 & 8 & - & - \\
Bacillus subtilis & 23 & 15 & 14 & 13 & - \\
Proteus vulgaris & 16 & 13 & 12 & 9 & - \\
Escherichia coli & 13 & 12 & - & - & - \\
Klebsiella pneumoniae & 15 & 12 & 11 & 9 & - \\
Psendomonas aeruginosa & 13 & 12 & 11 & 9 & - \\
Enterococcus spp. & - & - & - & - & - \\
Salmonella typhi & - & - & - & - & - \\
Candida albicans & 21 & 17 & 15 & 14 & 13 \\
\hline
\end{tabular}

Table (2): Antimicrobial activity of Hexane extract of Citrullus colocynthis seeds

\begin{tabular}{|c|c|c|c|c|c|}
\hline \multirow{2}{*}{ Tested micro organisms } & \multicolumn{5}{|c|}{$\begin{array}{l}\text { inhibition zone diameter }(\mathrm{mm}) \\
\text { concentrations }(\mathrm{mg} / \mathrm{ml})\end{array}$} \\
\hline & $\mathbf{5 0}$ & 25 & 12.5 & 6.25 & 3.1 \\
\hline Staphylococcus aureus & 12 & 9 & 7 & - & - \\
\hline Streptococcus pyogenes & 10 & 8 & - & - & - \\
\hline Listeria monocytogenes & 8 & 7 & - & - & - \\
\hline Bacillus subtilis & 8 & 7 & - & - & - \\
\hline Proteus vulgaris & - & - & - & - & - \\
\hline Escherichia coli & 8 & - & - & - & - \\
\hline Klebsiella pneumoniae & 7 & - & - & - & - \\
\hline Psendomonas aeruginosa & 8 & 7 & - & - & - \\
\hline Enterococcus spp. & - & - & - & - & - \\
\hline Salmonella typhi & - & - & - & - & - \\
\hline Candida albicans & 15 & 13 & 10 & - & - \\
\hline
\end{tabular}

There was no inhibition zones for $S$. typhi, Enterococcus sp and P. vulgaris. Candida albicans was sensitive to (50-12.5) $\mathrm{mg} / \mathrm{ml}$. 
Antimicrobial activity of extracts of fruits, leaves, stems and roots of citrullus colocynthis was observed against Bacillus subtilis, Bacillus pumilus, Staphylococcus, K. pneumoniae, and no activity was observed against P.aeruginosa, E. coli $[12,13]$.

The mechanism of action of antimicrobial effects of the extracts is by their affect on basic and common key processes in the organisms, as the presence of glycosides which can get hydrolyzed to release phenolics which toxic to microbial pathogens [14] or impairment of variety of enzyme systems including those involved in energy production and structural component synthesis [15]

The results showed Gram negative bacteria were to be more resistant than Gram positive bacteria, the resistance of Gram negative bacteria towards antibacterial substances is related to lipopolysacharides in their outer membrane.

The principle of dissolving chemicals (like dissolves like) is usually to draw different types of chemical materials, for example ethanol is a polar solvents, it polar factor is up to 5.2 degrees. and based on the degree of passive electrons, so most polar compounds ethyl alcohol. On the other hand non polar solvent such as hexane was used for extraction which linked through Van der walls forces [16].

Citrullus colocynthis seeds extracts also showed anti inflammatory activity [17] and anti diabetic effect [18]. This investigation indicated that Citrullus colocynthis used in herbal medicinal do possess antimicrobial activity against the microbes tested. These results can lead to further studies to isolate active compounds, and to study the activity against wider range of microorganisms with the goal of finding new therapeutic principles.

\section{References}

1. Poole, K. (2001). Overcoming antimicrobial resistance by targeting resistance mechanisms. J. Pharmacy and Pharmacology. 53(5):283-284.

2. Enne, V.I.; Livermore, D.M.; Stephens, P. and Hall, L.M. (2001). Persistance of sulfonamide resistance in Escherichia coli in the UK despite national prescribing restrictions. The Lancet. 28(8):1325-1328.

3. Islam, M.; Azhar, I. and Mazhar, F. et al. (2002). Evaluation of antibacterial activity of bergeniaciliata. Pak. J. Pharm. Sci. 15(1):35-42.

4. Khan, F.Z. and Saeed, M.A. (2003). Phytochemical and antimicrobial studies of salvia splenders sello. Pak. J. Pharm. Sci. 16(1):1-6.

5. Ng, T.J. (1993). New opportunities in the cucurbitaceae. J. Janick and J.E. Simon (eds). Newcrops.Wily Newyork.

6. Meena, M.C. and Patni, V. (2008). Isolation and identification of Flavonoid "Quercetin" from citrullus colocynthis (Linn) schrad. Asian J. Exp. Sci .22(1):137-147.

7. Yaniv, Z.; Shabelsky, E. and Schafferman, D. (1999). Colocynth: Potential Aridl and oil seed from an ancient cucurbit. J. Janick (ed).

8. Al-Khalifa, A.S. (1996). Physioctsemical characteristics, fatty acid composition and lipoxygenase activity of crude pumpkin and melon seed oils. J. Agr. Food. Chem. 44(3):964-966.

9. Lin, J.; Opoku, A.R.; Geheeb-Keller, M.; Hutchings, A.D.; Terblanch, J.; Jager, A.K. and Vanstaden, J. (1999). Preliminary screening of some traditional zulu medicinal plants for anti inflammatory and antimicrobial activity. J. Ethnopharmacol. 68(5):267-274. 
10. Anesini, C. and Perez, C. (1993). Screening of plants used in Arentine folk medicine for antimicrobial activity. J. Ethnopharmcology. 39(2):119-128.

11. Bonjar, S. (2004). Evalution of antibacterial properties of some medicinal plants used in Iraq. J. of. Ethnopharmacol.94:30-305.

12. Memon, U.; Brohi, A.; Ahmed, S.W.; Azhar, I. and Bano, H. (2003). Antibacterial screening of citrullus colocynthis. Pak. J. Pharm. Sci. 16(1):1-6.

13. Wasfi, I.A. (1994). Some pharmacological studies on citrullus colocynthis j.of Herbs, spices and medicinal plants vol(20); $\mathrm{N}(20)$.

14. Aboaba, O. and B.M.Efuwape(2001). Antibacterial properties of some Nigerian spices. Bio.res.comm.

15. Conner, D.E.and L. Beuchat (1984) Sensitivity of heat stressed yeasts to essential oils of plants. Applied Environ.microbial.

16. Lister, T.and Renshaw, J.1991. Understanding Chemistry for Advanced Level. $2^{\text {nd }}$ Edition, Stanley and Tome. London.

17. Mahdavi, R.; Dashti, N.; Ostadrahinti, A.; Delazar, A. and Rezazadeh, H. (2005). Antidiabetic effect of Citrullus colocynthis fruit aqueous extract on plasma glucose levels in diabetic rabbits. Pak. J. Pharm. Sci.

18. Winkel-Shirley, B. (2002): Biosynthesis of flavonoids and effects of stress. Curr. Opin. Plant Biol., 5, 218-223. 